\title{
Low dose $\alpha$ interferon therapy can be effective in chronic active hepatitis $C$. Results of a multicentre, randomised trial
}

J M Sánchez-Tapias, X Forns, S Ampurdanés, L Titó, R Planas, J M Viver, D Acero, M Torres, P Mas, R Morillas, M Forné, J Espinós, J M Llovet, J Costa, E Olmedo, F X López-Labrador, M T Jiménez de Anta, J Rodés

Liver Unit

J M Sánchez-Tapias

$\mathrm{X}$ Forns

$S$ Ampurdanés

L Titó

J Rodés

and Service of Microbiology

J Costa

E Olmedo

F X López-Labrador

M T Jiménez de Anta

Hospital Clinic, University of

Barcelona, Spain

Service of Internal Medicine, Hospital de L'Esperit Sant, Santa Coloma de Gramenet, Spain

T Tito

$M$ Torres

Service of Digestive

Diseases, Hospital

Germans Trias,

Badalona, Spain

R Planas

$R$ Morillas

J M Llovet

Service of Digestive Diseases, Hospital

Mutua de Tarrasa,

Spain

$\mathrm{J} M$ Viver

M Forné

Service of Digestive Diseases, Hospital de Girona, Spain

D Acero

Service of Internal Medicine, Hospital Parc Taulí, Sabadell, Barcelona, Spain

$P$ Mas

J Espinós

Correspondence to:

Dr J M Sánchez-Tapias,
Liver Unit, Hospital Clinic, Liver Unit, Hospital Barcelona, Spain.

Accepted for publication

9 October 1995

\begin{abstract}
Background-There is some controversy concerning the efficacy of low dose $\alpha$ interferon therapy in chronic hepatitis $C$. Aims-To evaluate the effectiveness of treatment with low doses of $\alpha$ interferon in chronic hepatitis $\mathbf{C}$.

Patients-One hundred and forty one patients with anti-HCV positive chronic active hepatitis $\mathbf{C}$ from six hospitals were enrolled in the study.

Methods-Patients were randomised to treatment with $5 \mathrm{MU}$ (group A) or $1.5 \mathrm{MU}$ (group B) injections. The dose was reduced in responders from group $A$ or increased in non-responders from group $B$ to maintain treatment with the minimal effective dose. Patients were treated for $\mathbf{4 8}$ weeks and followed up for 24 additional weeks with no treatment. Normalisation of alanine aminotransferase (ALT) was used to evaluate response.
\end{abstract}

Results-A sustained response was seen in eight patients from group $A(12 \%)$ and in $15(21 \%)$ from group B. This difference was not statistically significant. Increasing the dose of interferon led to sustained response in only five of 58 patients $(9 \%)$ from group $B$ who did not respond to 1.5 MU injections. In contrast, 15 of 21 patients $(71 \%)$ in whom ALT remained normal with $1.5 \mathrm{MU}$ injections developed a sustained response. By multivariate analysis sustained response seemed associated with young age and was more frequent in patients with genotype $3 \mathrm{HCV}$ infection. Sustained response was preceded by a rapid normalisation of ALT and was inversely related to the amount of $\alpha$ interferon necessary to maintain ALT at low values during treatment.

Conclusions-Some patients with chronic hepatitis $C$ are very sensitive to $\alpha$ interferon and can be successfully treated with low doses. Treatment with higher doses may be effective in a minority of patients who do not respond to low doses.

(Gut 1996; 38: 603-609)

Keywords: hepatitis $\mathrm{C}$ therapy, hepatitis $\mathrm{C}$ virus, interferon.

Chronic infection with the hepatitis $C$ virus (HCV) is the main cause of chronic hepatitis in Western countries and in Japan. ${ }^{1-3}$ Chronic hepatitis $\mathrm{C}$ is a serious condition because it may lead to development of cirrhosis of the liver and hepatocellular carcinoma. ${ }^{4-7}$

Administration of $\alpha$ interferon is currently accepted as a treatment for chronic hepatitis $\mathrm{C}$ because $\alpha$ interferon inhibits HCV replication and induces remission of the activity of the disease in some cases. ${ }^{8-12}$ Eradication of the infection after $\alpha$ interferon therapy has recently been reported. ${ }^{13}$

However, important problems concerning $\alpha$ interferon therapy in chronic hepatitis $C$ remain unsolved. Many patients do not respond to this treatment and many others relapse almost immediately after withdrawal of the treatment. In addition, $\alpha$ interferon is expensive and often causes adverse reactions, which occasionally are serious. ${ }^{14}$

As most of the unwanted side effects of interferon are dose related, ${ }^{15}$ treatment with low doses might be preferable. However, it is uncertain if low dose interferon therapy is effective in chronic hepatitis C. In a multicentre study, Davis et al observed that treatment with $1 \mathrm{MU}$ per injection three times a week for six months was less effective than treatment with $3 \mathrm{MU}$ injections. ${ }^{16}$ Similar findings arose from two smaller studies carried out in France. ${ }^{17} 18$ In comparison with lower doses, however, the advantages of treatment with $3 \mathrm{MU}$ injections were less clear in a large Italian study ${ }^{19}$ and, recently, Reichen et al showed that treatment with 1.5 MU three times a week for 12 months produced results in the range of those obtained with higher interferon doses. ${ }^{20}$ Indeed, treatment with minimal amounts of $\alpha$ interferon, as low as $0.25 \mathrm{MU}$ three times a week ${ }^{21}$ or weekly $6 \mathrm{MU}$ injections ${ }^{22}$ can produce beneficial effects in some patients.

This multicentre randomised study aimed to evaluate the effectiveness of low dose interferon therapy in chronic hepatitis C. To this purpose, a large number of patients were randomised to be treated with decreasing or increasing doses of interferon depending on the response to comparatively high ( $5 \mathrm{MU}$ per injection) or low (1.5 MU) doses given initially, respectively.

\section{Methods}

PATIENTS

One hundred and forty one consecutive patients with chronic active hepatitis $\mathrm{C}$ participated in the study. They were recruited in six 
hospitals located in the Barcelona area from October 1989 to January 1991. Admission criteria included: (a) increased alanine aminotransferase (ALT) serum concentrations above 2.5 times the normal value ( $40 \mathrm{IU} / \mathrm{l})$ on at least two separate occasions during the six month period preceding randomisation and (b) chronic active hepatitis with or without cirrhosis confirmed by percutaneous liver biopsy. Evidence of hepatitis $C$ virus infection was not a criteria for selection because specific tests were not universally available at the beginning of enrolment. Anti-HCV antibodies were positive, however, in all the cases when tested retrospectively with a second generation enzyme linked immunosorbent assay (ELISA) test (Ortho Diagnostic Systems, Raritan, NJ, USA).

Patients with current HBV infection (positive HBsAg), alcohol abuse, autoimmune hepatitis (presence of antinuclear, antimitochondrial, antismooth muscle, or anti-LKM non-organ specific autoantibodies with a titre value higher than 1:40), drug induced or metabolic liver disease were not considered for inclusion. Other exclusion criteria were: age lower than 18 years or higher than 65 years, HIV infection, histological diagnosis of chronic persistent hepatitis or minimal liver lesions, past or current hepatic decompensation, previous treatment with antiviral or immunomodulatory agents, leucocyte count below $3 \times 10^{6} /$, platelet count below $75 \times 10^{6} / 1$, pregnancy or presence of any significant pathological condition other than hepatitis.

\section{Randomisation and treatment schedules}

According to histological features, patients were stratified in three categories: chronic active hepatitis, chronic active hepatitis with bridging fibrosis, or bridging necrosis and chronic active hepatitis with cirrhosis. Patients from each histological category were randomised to treatment with decreasing doses of interferon (group A) or with increasing doses (group B) by computer generated random numbers.

Group $A$ - interferon $\alpha 2 \mathrm{~b}$ was given by subcutaneous injection three times per week during 48 weeks. Treatment was started with 5 MU injections. After 12 weeks of treatment the dose of interferon was adjusted according to individual response. In patients who showed a decrease of serum ALT greater than $50 \%$ the pretreatment values the dose of interferon was reduced to $3 \mathrm{MU}$ three times a week, which was given during the next 12 weeks. In patients with sustained response to $3 \mathrm{MU}$ of interferon the dose was further reduced to $1.5 \mathrm{MU}$ per injection for 24 additional weeks. In patients who had another increase in ALT upon dose reduction, the previously effective dose was reintroduced and this dose was maintained until the end of the treatment period with no further modification. Treatment was stopped in patients who did not show a $50 \%$ decrease of ALT after 16 weeks of treatment with $5 \mathrm{MU}$ three times a week.

Group $B$ - interferon was also given three times a week during 48 weeks. Treatment started with 1.5 MU injections. This dose was maintained during the entire treatment period in patients who achieved a $50 \%$ or greater reduction of ALT. In patients who did not respond to $1.5 \mathrm{MU}$ injections after eight weeks of treatment, the dose was increased to $3 \mathrm{MU}$ three times a week for eight additional weeks. The dose was then reduced to $1.5 \mathrm{MU}$ or increased to $5 \mathrm{MU}$ according to response. As in group $\mathrm{A}$, treatment was maintained with the minimal effective dose. Treatment was stopped if a $50 \%$ decrease of ALT did not occur after 16 weeks of treatment with $5 \mathrm{MU}$ injections.

\section{Examinations}

Complete clinical and biochemical examination, including liver function tests, serum glucose, creatinine, blood urea nitrogen, total protein, albumin, prothrombin time, and full blood cell count were carried out weekly during the first month of treatment and at least every four weeks during the remaining period of treatment and during the six months follow up after treatment.

Pretreatment serum samples from all the patients recruited at one of the participating centres (Hospital Clinic, Barcelona) were screened for the presence of specific antibodies against $\mathrm{HCV}$ types 1,2, and 3. Testing was performed at the Department of Medical Microbiology of the University of Edinburgh with an ELISA test in which synthetic peptides derived from the NS4 region of the HCV genome were used as antigen, as described. ${ }^{23}$

HCV-RNA in serum was examined in serial serum samples taken at baseline, after 12 and 48 weeks of treatment, and at the end of post-treatment follow up. Investigation was performed by polymerase chain reaction according to Simmonds et al, with minor modifications. ${ }^{24}$ In brief, RNA was extracted from $200 \mu \mathrm{l}$ of serum by the phenol/chloroform method ${ }^{25}$ and reverse transcribed to cDNA with random primers. cDNA was amplified by nested polymerase chain reaction using the two pairs of primers of the 5'UTR of the HCV genome described by Garson et al. ${ }^{26}$

TABLE I Pretreatment characteristics of patients included in the study ${ }^{\star}$

\begin{tabular}{|c|c|c|}
\hline Variable & $\begin{array}{l}\text { Group } A \\
(n=70)\end{array}$ & $\begin{array}{l}\text { Group B } \\
(n=71)\end{array}$ \\
\hline Age (y) & 49 (12) & $46(13)$ \\
\hline \multicolumn{3}{|l|}{ Sex } \\
\hline $\begin{array}{l}\text { males } n(\%) \\
\text { females } n(\%)\end{array}$ & $\begin{array}{l}39(56) \\
31(44)\end{array}$ & $\begin{array}{l}41(58) \\
30(42)\end{array}$ \\
\hline \multicolumn{3}{|l|}{ Presumed source of infection } \\
\hline blood transfusion $\mathrm{n}(\%)$ & $22(31)$ & $20(28)$ \\
\hline $\begin{array}{l}\text { intravenous drug abuse } \mathrm{n}(\%) \\
\text { unknown } \mathrm{n}(\%)\end{array}$ & $\begin{array}{c}2(3) \\
46(66)\end{array}$ & $\begin{array}{r}9(13) \\
42(59)\end{array}$ \\
\hline Aspartate aminotransferase (IU/l) & $133(72)$ & $139(73)$ \\
\hline Alanine aminotransferase (IUU/) & $236(146)$ & $272(177)$ \\
\hline$\gamma$ Glutamyltranspeptidase (IU/I) & $62(39)$ & $73(67)$ \\
\hline Platelet count $\left(\times 10^{6} / 1\right)$ & $174(51)$ & $179(63)$ \\
\hline White blood cell count $\left(\times 10^{6} / 1\right)$ & $5.9(1.9)$ & $6 \cdot 1(1 \cdot 8)$ \\
\hline \multicolumn{3}{|l|}{ Liver histology } \\
\hline CAH n (\%) & $33(47)$ & $37(52)$ \\
\hline CAH with bridging $\mathrm{n}(\%)$ & $28(40)$ & $24(34)$ \\
\hline CAH with cirrhosis $\mathrm{n}(\%)$ & $9(13)$ & $10(14)$ \\
\hline
\end{tabular}

^Quantitative data are expressed as mean (standard deviation). CAH: Chronic active hepatitis. 
TABLE II Relation between interferon dose and response in patients from group $A$

\begin{tabular}{|c|c|c|c|c|c|c|}
\hline Interferon dose & $\begin{array}{l}\text { Total } \\
\text { dose } \\
(M U)\end{array}$ & $\begin{array}{l}\text { No } \\
\text { of } \\
\text { cases }\end{array}$ & $\begin{array}{l}\text { Response } \\
n(\%)\end{array}$ & $\begin{array}{l}\text { No. } \\
\text { response } \\
n(\%)\end{array}$ & $\begin{array}{l}\text { Relapse } \\
n(\%)\end{array}$ & $\begin{array}{l}\text { Sustained } \\
\text { response } \\
n(\%)\end{array}$ \\
\hline $\begin{array}{l}\text { Maintained at } 5 \mathrm{MU}^{\star} \\
\text { Reduced to } 3 \mathrm{MU} \text { with later increase to } 5 \mathrm{MU} \\
\text { Reduced to } 3 \mathrm{MU} \text { and to } 1.5 \mathrm{MU} \text { with later increase to } 3 \mathrm{MU} \\
\text { Reduced to } 3 \mathrm{MU} \text { and to } 1.5 \mathrm{MU}\end{array}$ & $\begin{array}{l}240 \\
648 \\
450 \\
396\end{array}$ & $\begin{array}{l}17 \\
15 \\
21 \\
17\end{array}$ & $\begin{array}{l}0 \\
4(27) \\
8(38) \\
8(47)\end{array}$ & $\begin{array}{l}17(100) \\
11(73) \\
13(62) \\
9(53)\end{array}$ & $\begin{array}{l}0 \\
3(20) \\
6(29) \\
3(17)\end{array}$ & $\begin{array}{l}0 \\
1(7) \\
2(9) \\
5(30)\end{array}$ \\
\hline Total & & 70 & $20(29)$ & $50(71)$ & $12(17)$ & $8(12)$ \\
\hline
\end{tabular}

^Treatment was withdrawn in patients who did not respond after 16 weeks of treatment.

Definition of types of response

Response was defined by normalisation of ALT only when it was sustained until the end of the treatment period. Depending on events during follow up after treatment, two categories of response were defined: sustained response, defined by normalisation of ALT persisting until the end of the post-treatment follow up, and transient response, defined by normalisation of ALT at the end of treatment followed by relapse. Lack of normalisation of ALT at the end of treatment was considered no response.

\section{Statistical analysis}

Quantitative variables were expressed as mean (SD). The two tailed Student's $t$ test was used to compare continuous variables between two groups. Differences between dichotomous variables were evaluated with $\chi^{2}$ analysis or Fisher's exact test depending on the size of the sample. A multivariate analysis by stepwise logistic regression was performed to identify factors independently associated with response. Analysis was performed on an intention to treat basis and all calculations were made using a SPSS computer program.

The study protocol was approved by the ethics committee of each participating hospital and all patients gave their informed consent prior to randomisation.

\section{Results}

Of 141 patients enrolled in the study, 70 were randomised to receive treatment with decreasing doses of interferon (group A) and 71 to receive increasing doses of interferon (group B). The demographic, clinical, biochemical, and histological features of both groups were similar (Table I).

Twenty eight patients from each group did not complete 48 weeks of treatment. In 17 cases in group $A$ and in 18 in group B the treatment was interrupted after 16 weeks at the highest dose (5 MU three times a week) because ALT did not decrease to below 50\% pretreatment values, as scheduled in the study

TABLE III Relation between interferon dose and response in patients from group $B$

\begin{tabular}{lllllll}
\hline Interferon dose & $\begin{array}{l}\text { Total } \\
\text { dose } \\
(M U)\end{array}$ & $\begin{array}{l}\text { No } \\
\text { of } \\
\text { cases }\end{array}$ & $\begin{array}{l}\text { Response } \\
n(\%)\end{array}$ & $\begin{array}{l}\text { No } \\
\text { response } \\
n(\%)\end{array}$ & $\begin{array}{l}\text { Relapse } \\
n(\%)\end{array}$ & $\begin{array}{l}\text { Sustained } \\
\text { response } \\
n(\%)\end{array}$ \\
\hline Maintained at 1.5 MU & 216 & 27 & $13(48)$ & $14(52)$ & $3(11)$ & $10(37)$ \\
Increased to 3 MU & 396 & 24 & $10(42)$ & $14(58)$ & $6(25)$ & $4(17)$ \\
Increased to 5 MU & 588 & 20 & $2(10)$ & $18(90)$ & $1(5)$ & $1(5)$ \\
Total & & 71 & $25(35)$ & $46(65)$ & $10(14)$ & $15(21)$ \\
\hline
\end{tabular}

protocol. Treatment was interrupted because of development of side effects, including neutropenia, thrombocytopenia, severe depression or hyperthyroidism, in seven patients from group A and in five from group B. Treatment was interrupted for other reasons, such as subjective intolerance, travelling abroad or traffic accident in nine additional patients, four from group A and five from group B. No patient withdrawn from treatment was excluded from the study.

Of 70 patients included in group $A, 20$ (29\%) fulfilled the criteria for response defined above and $50(71 \%)$ did not (Table II). Response was transient in $12(17 \%)$ and sustained in eight (12\%). Corresponding figures for the 71 patients in group B were: $25(35 \%)$ for response, $46(66 \%)$ for no response, 10 (14\%) for transient response, and $15(21 \%)$ for sustained response (Table III). Thus, there was a trend for better response in patients treated with lower dose of interferon but the difference did not reach statistical significance.

Complete normalisation of ALT at the end of treatment seemed inversely related to the amount of interferon necessary to induce a decrease of ALT below $50 \%$ of the pretreatment values. This was particularly evident in group $\mathrm{B}$, where the proportion of responders seen among patients treated exclusively with 1.5 MU injections (total dose $216 \mathrm{MU}$ ) was significantly greater than in patients who required an increase in the amount of interferon given per injection up to $5 \mathrm{MU}$ (total dose 588 MU) to keep ALT low (48\% $v 10 \%$; Fisher's exact test, $p=0.005$ ) (Table III). In group A there was also a trend for better response among patients treated with $1.5 \mathrm{MU}$ injections only (total dose of $396 \mathrm{MU}$ ) than in those requiring treatment with $3 \mathrm{MU}$ or $5 \mathrm{MU}$ injections (total dose 450 to $648 \mathrm{MU}$ ) (Table II).

The proportion of patients with sustained response after interferon withdrawal was also higher among patients treated with low interferon dose. In group A, sustained response was recorded in five of 17 patients $(30 \%)$ in whom interferon administration could be reduced to 1.5 MU per injection (total dose $396 \mathrm{MU}$ ) but in only three of $36(8 \%)$ who received greater amounts of interferon (total dose 450 or 648 MU) ( $p=0.05$, Fisher's exact test) (Table II). In group B, sustained response was seen in 10 of 27 patients $(37 \%)$ treated exclusively with $1.5 \mathrm{MU}$ injections (total dose $216 \mathrm{MU}$ ) and in five of $44(13 \%)$ treated with higher doses (total dose 396 or $588 \mathrm{MU}$ ) ( $\mathrm{p}=0.01$, Fisher's exact test) (Table III).

In contrast, relapse upon interferon withdrawal seemed directly related to the amount 
TABLE IV Relation between normalisation of serum alanine aminotransferase (ALT) early during treatment and the type of response

\begin{tabular}{llcc}
\hline & & \multicolumn{2}{c}{ Patients with normal ALT } \\
\cline { 3 - 4 } \cline { 3 - 4 } & $\begin{array}{l}\text { No of } \\
\text { cases }\end{array}$ & $\begin{array}{l}\text { At 4 weeks } \\
n(\%)\end{array}$ & $\begin{array}{l}\text { At 8 weeks } \\
n(\%)\end{array}$ \\
\hline Non-responders & 96 & $3(3)^{\star}$ & $4(4)$ \\
Responders & 45 & $21(47)$ & $31(69)$ \\
Sustained responders & 23 & $13(56)$ & $18(78)$ \\
Transient responders & 22 & $8(36)$ & $13(59)$ \\
\hline
\end{tabular}

^Non-responders $v$ responders at 4 weeks: difference between proportions $=0.435,95 \% \mathrm{CI} 0.286$ to $0.585, \mathrm{p}<0.000$; at 8 weeks: difference between proportions $=0.647,95 \% \mathrm{CI} 0.506$ to $0.788, p<0.000$.

of interferon that was necessary to maintain low ALT values during treatment. In group A, relapse occurred in three of eight $(37 \%)$ patients who maintained response with 1.5 MU doses and in nine of $12(75 \%)$ patients who required $3 \mathrm{MU}$ or $5 \mathrm{MU}$ doses (Table II). In group $B$, relapse occurred in three of 13 $(23 \%)$ patients with normal ALT while treated with $1.5 \mathrm{MU}$ dose and in seven of $12(58 \%)$ who required three or five MU doses (Table III). These differences were not statistically significant. When responders from both groups were pooled, however, it became apparent that relapse occurred in six of 21 patients $(29 \%)$ who maintained response with $1.5 \mathrm{MU}$ and in 16 of 24 patients $(67 \%)$ who required higher dose of interferon to maintain ALT at normal values during treatment (Fisher's exact test, $\mathrm{p}=0 \cdot 01$ ).

Rapid normalisation of ALT after the start of treatment was associated with response. Normalisation of ALT after four or eight weeks of treatment was more frequent in responders (47\% and $69 \%$ respectively), particularly in those with sustained response (56\% and $78 \%$ ), than in non-responders (3\% and 4\%). These differences were statistically significant. The frequency of rapid normalisation of ALT in sustained responders was somewhat greater than in transient responders but the difference was not statistically significant (Table IV).

Responders and non-responders were compared to investigate factors associated with response (Table V). Univariate analysis showed that responders were significantly younger than

TABLE V Factors associated with response to interferon therapy ${ }^{\star}$

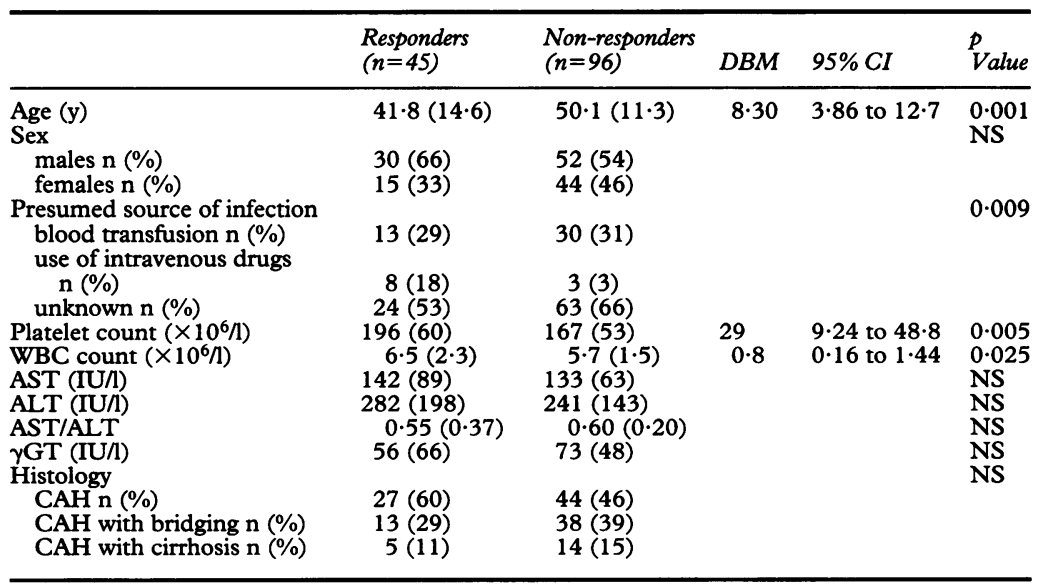

${ }^{\star}$ Quantitative data are expressed as mean (SD). Responders includes patients with sustained or transient response. DBM, difference between means for quantitative variables. WBC $=$ white blood cell, $\gamma \mathrm{GT}=\gamma$ glutamyltranspeptidase, $\mathrm{CAH}=$ chronic active hepatitis. non-responders. History of intravenous drug abuse in the past was more common in responders. No significant differences in serum aspartate aminotransferase (AST) nor ALT activity were found but platelet and white blood cell counts were significantly higher in responders. The degree of histological severity was similar in responders and non-responders. Multivariate analysis showed that only age had independent predictive value of response.

Univariate analysis of baseline features disclosed several differences between patients with and without sustained response. Sustained responders were younger and their platelet count and AST/ALT ratio were higher than in non-sustained responders. History of intravenous use of drugs was more frequent in sustained responders. The degree of histological severity was similar in both groups (Table VI). Sustained response occurred, however, in 16 of 71 patients $(23 \%)$ with preserved lobular architecture but in only seven of $70(10 \%)$ with changed lobular architecture by the presence of bridging fibrosis or cirrhosis (difference between proportions $0 \cdot 125,95 \%$ confidence intervals 0.0054 to $0.245, p=0.04$ ). Multivariate analysis showed that only age was independently associated with sustained response.

Fifty four patients recruited at a single centre were screened for specific antibodies against HCV genotypes 1,2 , and 3 . Thirty two $(59 \%)$ reacted for type 1 , one $(2 \%)$ for type 2 , five $(9 \%)$ for type 3 , five $(9 \%)$ for genotypes 1 , and two and $11(20 \%)$ did not react or gave non-type specific reaction. The response to interferon in these 54 patients did not differ from that seen in the remaining 87 nonscreened patients recruited in other centres. Table VII shows the relation between $\mathrm{HCV}$ serotype and response to treatment. The proportion of patients who showed sustained response was significantly higher in patients with HCV genotype 3 or with an unidentified $\mathrm{HCV}$ genotype than in those infected with genotype 1 (Fisher's exact test, $p=0.0048$ and $\mathrm{p}=0.012$ respectively). Of the 10 patients with sustained response, seven were treated with low dose interferon and four of them were infected by serotype 3 of $\mathrm{HCV}$. In patients infected with HCV serotype 1, a sustained response after treatment with $1.5 \mathrm{MU}$ injections was achieved in one case only.

HCV-RNA was investigated in serum samples taken before, during, and after treatment in the 54 patients screened for $\mathrm{HCV}$ serotypes. HCV-RNA was positive in all the cases before treatment. The proportion of patients in whom HCV-RNA became negative was greater in responders than in nonresponders (Table VIII) although three patients with sustained biochemical response still had detectable HCV-RNA in serum by nested polymerase chain reaction six months after completion of treatment. However, HCV-RNA became negative when these patients were re-tested one year later.

The rate of negative values of HCV-RNA seen after 12 weeks of treatment, at the end of treatment, and at the end of follow up in groups A and B was similar. 
TABLE VI Factors associated with sustained response to interferon therapy*

\begin{tabular}{|c|c|c|c|c|c|}
\hline & $\begin{array}{l}\text { Sustained } \\
\text { responders } \\
(n=23)\end{array}$ & $\begin{array}{l}\text { Others } \\
(n=118)\end{array}$ & $D B M$ & $95 \% C I$ & Palue \\
\hline \multirow{11}{*}{ 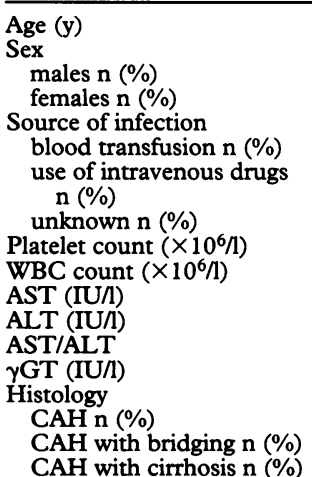 } & $37 \cdot 5(16 \cdot 2)$ & $49 \cdot 5(11 \cdot 4)$ & \multirow[t]{6}{*}{12} & \multirow[t]{6}{*}{6.46 to 17.5} & \multirow{2}{*}{$\begin{array}{l}0.002 \\
\text { NS }\end{array}$} \\
\hline & $\begin{array}{r}14(61) \\
9(39)\end{array}$ & $\begin{array}{l}68(58) \\
50(42)\end{array}$ & & & \\
\hline & & & & & \multirow[t]{3}{*}{0.021} \\
\hline & $7(30)$ & $36(31)$ & & & \\
\hline & $\begin{array}{r}5(22) \\
11(48)\end{array}$ & $\begin{array}{c}6(5) \\
76(64)\end{array}$ & & & \\
\hline & $203(72)$ & $171(53)$ & & & \multirow{6}{*}{$\begin{array}{l}\text { NS } \\
0 \cdot 042 \\
\text { NS } \\
\text { NS } \\
0 \cdot 000 \\
\text { NS } \\
\text { NS }\end{array}$} \\
\hline & $\begin{array}{r}6 \cdot 8(2 \cdot 9) \\
147(101)\end{array}$ & $\begin{array}{c}5 \cdot 8(1 \cdot 8) \\
134(65)\end{array}$ & 1 & 0.092 to 1.91 & \\
\hline & $319(235)$ & $242(144)$ & & & \\
\hline & $\begin{array}{l}0.46(0.09) \\
51(41)\end{array}$ & $\begin{array}{l}0.61(0 \cdot 28) \\
71(57)\end{array}$ & \multirow[t]{3}{*}{1.50} & \multirow[t]{3}{*}{0.033 to 0.267} & \\
\hline & & & & & \\
\hline & $\begin{array}{r}16(70) \\
5(22) \\
2(8)\end{array}$ & $\begin{array}{l}55(47) \\
46(39) \\
17(14)\end{array}$ & & & \\
\hline
\end{tabular}

*Quantitative data are expressed as mean (SD). Abbreviations as in Table V.

\section{Discussion}

The potential value of $\alpha$ interferon therapy for the treatment of chronic non-A, non-B hepatitis was recognised in 1986, several years before the identification of $\mathrm{HCV}$ as the agent responsible for this disease. ${ }^{27}$ To assess the effectiveness of this treatment several controlled trials were set up and a recent meta analysis of these studies showed that $\alpha$ interferon can induce remission of the disease in about one half of treated patients although one half of responders will relapse when the treatment is stopped. ${ }^{28}$

In this study only 22 of 141 patients (15.6\%) had a sustained response. This low proportion of responders is possibly due to patient selection because this study did not include patients with a low index of histological activity or chronic persistent hepatitis, who are believed to respond better to interferon. ${ }^{29} 30$ In fact, about one half of the patients selected for inclusion had either cirrhosis or chronic active hepatitis with bridging fibrosis and distorted lobular architecture, which are factors associated with a poor response to interferon therapy. ${ }^{29} 3132$

Previous studies have suggested that, beside these histopathological features, the response to $\alpha$ interferon therapy may also be related to other circumstances. Among host related factors, old age, ${ }^{173334}$ long duration of the disease, ${ }^{32} 35$ excessive body weight, ${ }^{30} 35$ increased $\gamma$ glutamyltranspeptidadse, ${ }^{34} 36$ and iron overload ${ }^{33}$ have all been associated with diminished response to interferon. Recently, factors directly related to the causative agent, such as $\mathrm{HCV}$ genotype $^{3738}$ or the amount of HCV-RNA

TABLE VII Relation between HCV serotype and the type of response to interferon therapy

\begin{tabular}{lcccc}
\hline \multicolumn{5}{c}{ Type of response } \\
\cline { 2 - 5 } HCV serotype & $\begin{array}{l}\text { No of } \\
\text { cases }\end{array}$ & $\begin{array}{l}\text { Sustained } \\
n(\%)\end{array}$ & $\begin{array}{l}\text { Transient } \\
n(\%)\end{array}$ & $\begin{array}{l}\text { Absent } \\
n(\%)\end{array}$ \\
\hline Type 1 & 32 & $4(12)$ & $7(22)$ & $21(66)$ \\
Type 2 & 1 & 0 & 0 & $1(100)$ \\
Type 3 & 5 & $4(80)$ & 0 & $1(20)$ \\
Type 1+2 & 5 & $1(20)$ & $1(20)$ & $3(60)$ \\
Not identified & 11 & $1(9)$ & $4(36)$ & $6(55)$ \\
Total & 54 & $10(19)$ & $12(22)$ & $32(59)$ \\
\hline
\end{tabular}

detected in serum ${ }^{1039}$ have also emerged as important determinants of response.

The dose of interferon and the duration of treatment can also influence the effectiveness of the treatment. The probability of permanent response seems greater if treatment is given for at least 12 months ${ }^{4041}$ and a high rate of sustained response in patients treated for 60 weeks has recently been reported. ${ }^{42}$ The influence on response of the dose of interferon is more controversial because the results of studies showing that low dose is less effective than high dose therapy ${ }^{16-18}$ do not agree with other findings. ${ }^{192041}$ To evaluate the influence of the dose administered on the final result of the treatment is an important issue because $\alpha$ interferon is expensive and often produces undesirable side effects, which are dose related.

The main objective of this study was to compare the effectiveness of two different schedules of $\alpha$ interferon therapy given for 48 weeks. To this purpose, a large group of patients with chronic active hepatitis $C$ were randomised to receive $\alpha$ interferon at increasing or decreasing doses, starting from 1.5 MU or $5 \mathrm{MU}$ per injection respectively, according to response. In contrast with other studies aimed at comparing fixed doses of interferon, the design of this trial permitted the administration of increasing amounts of interferon in those patients who failed to respond to lower doses, according to a strategy that may be effective in some patients. ${ }^{43}$

There were no differences in the rate of response seen in patients treated with low, increasing dose in comparison with those treated with high, decreasing dose. In fact, the proportion of patients who responded, either transiently or permanently, was slightly greater in patients who started treatment with a low dose of interferon. As patients from both groups were comparable, it may be suggested that the effectiveness of the two therapeutic schedules evaluated in this study was similar.

Beside the possible role of low dose interferon therapy in chronic hepatitis $C$, other aspects of this study deserve further comment. Firstly, about two thirds of the patients who developed a sustained response were able to respond or to maintain ALT, or both below the upper normal limit with $1.5 \mathrm{MU}$ injections of interferon. Secondly, sustained response was strongly associated with a rapid fall of ALT, as previously noted by others. ${ }^{44}$ In this study, ALT became normal within the eight initial weeks of treatment in $78 \%$ of the patients who developed later a sustained response, including those who started treatment with low doses of

TABLE VII Detectability of HCV-RNA in serum before, during, and after interferon therapy according to the type of biochemical response

\begin{tabular}{lcll}
\hline & $\begin{array}{c}\text { Sustained } \\
(n=10)\end{array}$ & $\begin{array}{l}\text { Transient } \\
(n=12)\end{array}$ & $\begin{array}{l}\text { Absent } \\
(n=32)\end{array}$ \\
\hline Before therapy n (\%) & $10(100)$ & $12(100)$ & $32(100)$ \\
At week 12 of therapy $\mathrm{n}(\%)$ & $5(50)$ & $8(67)$ & $27(84)$ \\
At the end of therapy $\mathrm{n}(\%)$ & $5(50)$ & $9(75)$ & $27(84)$ \\
At the end of follow up n (\%) & $3(30)$ & $12(100)$ & $29(91)$ \\
\hline
\end{tabular}


interferon. In contrast, rapid normalisation of ALT was very rare in non-responders from the two study groups.

These findings suggest that some patients with chronic $\mathrm{HCV}$ infection are very sensitive to interferon whereas other patients are refractory to this treatment. Distinction between these two categories has important implications. In this study the small number of patients who presented a sustained response to low dose interferon made difficult the identification of the features that characterise sustained responders. Comparison of sustained responders, most of whom achieved response with low dose treatment, with non-sustained responders, showed that young age, obvious parenteral exposure to infection, and particularly history of addiction to intravenous drugs in the past, high AST/ALT ratio, and preserved lobular architecture were associated with complete response. Each of these variables has been recognised as a marker of favourable response in previous studies where patients received higher doses of interferon. ${ }^{30}$ In this study, however, logistic regression analysis showed that only young age was independently related to good response.

The influence of virological factors on the response to treatment was analysed in more than one third of the patients by testing for HCV serotype and serum HCV-RNA. Sustained response, even to low dose of interferon, seemed associated with infection with HCV serotype 3 whereas most patients infected with HCV serotype 1 did not respond or relapsed. These findings are in agreement with recent observations from other large serological surveys of patients with chronic hepatitis $C$ treated with different interferon schedules. ${ }^{45-47}$ In these studies it has been shown that $\alpha$ interferon therapy is less effective in patients with chronic hepatitis caused by serotype $1 \mathrm{HCV}$ than in patients infected by other HCV serotypes.

There is increasing evidence that a low level of viraemia is associated with longterm response to interferon therapy in chronic hepatitis C. 103948 Unfortunately, serum HCV-RNA was not assessed because properly processed and stored serum samples ${ }^{49}$ obtained at baseline were not available from many patients. We have recently reported, however, a good correlation between low HCV-RNA serum concentration and a satisfactory response to interferon in a large series of patients from our hospital who otherwise presented similar features to those included in this study. ${ }^{50}$ Therefore, the presence of low levels of viraemia in sustained responders from the present series is likely.

As noted previously, 19 serum HCV-RNA sequences were detected by nested polymerase chain reaction despite sustained biochemical remission in three of 10 patients. Although these subjects cleared HCV-RNA when tested one year later, the meaning and the prognostic implications of the presence of HCV-RNA in patients undergoing normalisation of ALT under interferon therapy is currently uncertain.
In summary, administration of $1.5 \mathrm{MU}$ of $\alpha$ interferon three times a week for 48 weeks was sufficient to induce sustained biochemical remission in about $15 \%$ of patients with chronic active hepatitis $C$ in an area where genotype 1 is highly prevalent. Response to such a low dose of interferon can be expected in young patients infected with HCV genotype 3 and, possibly, low level of viraemia. Sustained response was heralded by rapid normalisation of ALT. Increasing the dose of interferon induced response in some patients who did not respond rapidly to low doses but most of them relapsed upon interferon withdrawal. Initial treatment with $5 \mathrm{MU}$ injections followed by tapered doses in responding patients did not increase the efficiency of treatment with 1.5 MU initial doses. Failure of $\alpha$ interferon therapy is likely in patients with chronic active hepatitis $\mathrm{C}$ who do not respond rapidly to low dose $\alpha$ interferon therapy. In these patients, treatments other than $\alpha$ interferon given alone must be prospectively investigated. As relapse may still occur in patients responding to 48 week low dose therapy, treatment for longer periods of time deserves further evaluation.

This study was supported in part by grants $91 / 360$ and 94.848 from Fondo de Investigaciones Sanitarias del Ministerio de Sanidad. X Forns, F X López-Labrador, and E Olmedo receive grants from Hospital Clinic, Ministerio de Educación y Ciencia, and Fundació Catalana per L'Estudi del Fetge respectively.

The authors are grateful to Dr P Simmonds for serotyping studies.

1 Sánchez-Tapias JM, Barrera JM, Costa J, Ercilla MG, Parés $\mathrm{A}$, Comalrrena $\mathrm{Ll}$, et al. Hepatitis $\mathrm{C}$ virus infection in nonalcoholic chronic liver diseases. Ann Intern Med 1990; 112: $921-4$.

2 Jeffers LJ, Hasan F, de Medina M, Reddy R, Parker T, Silva $M$, et al. Prevalence of antibodies to hepatitis $C$ virus among patients with cryptogenic chronic hepatitis and among patients with cryptogenic chroni

3 Hosoda K, Omata M, Yokosuka O, Kato N, Ohto M. Non$A$, non-B chronic hepatitis is chronic hepatitis C: a sensiA, non-B chronic hepatitis is chronic hepatitis C: a sensitive assay for detection of hepatitis

4 Hopf U, Möller B, Küter D, Stemerowicz R, Lobeck H, Lüdtke-Handjery, et al. Long-term follow up of posttransfusion and sporadic chronic hepatitis non- $A$, non- $B$ and frequency of circulating antibodies to hepatitis $\mathrm{C}$ virus (HCV). F Hepatol 1990; 10: 69-76.

5 Tremolada F, Casarin C, Alberti A, Drago C, Tagger A Ribero ML, et al. Long term follow-up of non-A, non-B (type C) post-transfusion hepatitis. 7 Hepatol 1992; 16: 273-81.

6 Di Bisceglie AM, Goodman ZD, Ishak KG, Hoofnagle JH, Melpolder JJ, Alter HJ. Long term clinical and histopathological follow-up of chronic posttransfusion hepatitis. logical follow-up of chronic
Hepatology 1991; 14: 969-74.

7 Kiyosawa K, Akahane Y, Nagata A, Furata S Hepatocellular carcinoma after non-A, non-B posttransfusion hepatitis. Am $\mathcal{F}$ Gastroenterol 1984; 79: 777-81.

8 Shindo M, DiBisceglie AM, Cheung L, Shih WK, Cristiano $\mathrm{K}$, Feinstone SM, et al. Decrease in serum hepatitis C virus RNA during alpha interferon therapy for chronic hepatitis C. Ann Intern Med 1991; 115: 700-4.

9 Chayama K, Saitoh S, Arase Y, Ikeda K, Matsumoto T, Sakai $Y$, et al. Effect of interferon administration on serum hepatitis $C$ virus RNA in patients with chronic hepatitis $C$. Hepatology 1991; 13: 1040-3.

10 Hagiwara H, Hayashi N, Mita E, Takehara T, Kasahara A Fusamoto $\mathrm{H}$, et al. Quantitative analysis of hepatitis $\mathrm{C}$ virus RNA in serum during interferon alpha therapy. virus RNA in serum during interfer

11 David E, Pucci A, Palladin D, Saracco G, Garello E, Pintus $\mathrm{C}$, et al. Histologic changes in liver biopsy specimens produced by recombinant interferon alpha-2b therapy for duced by recombinant interferon alpha-2b therapy for chronic non-A, non-B viral hepatitis. A randomi
controlled trial. Am 7 Clin Pathol 1992; 98: 397-401.

12 Marcellin P, Boyer N, Martinot-Peignoux M, Areias J Giostra E, Degott C, et al. Long-term histological improvement and persistent HCV replication in patients with chronic hepatitis $C$ having responded to recombinan alpha interferon. In: Nishioka $K$, Suzuki $H$, Mishiro $S$ Oda $\mathrm{T}$, eds. Viral hepatitis and liver disease. Tokyo: Springer-Verlag, 1994: 635-7.

13 Romeo R, Pol S, Berthelot P, Brechot C. Eradication of hepatitis $\mathrm{C}$ virus RNA after alpha-interferon therapy. Ann Intern Med 1994; 121: 276-7. 
14 Janssen HLA, Brouwer JT, Nevens F, Sánchez-Tapias JM, Craxi A, Hadzyannis SJ. Fatal hepatic decompensation associated with interferon alpha. BMF 1993; 306: 107-8. 15 Renault PF, Hoofnagle JH. Side effects of alpha interferon Semin Liver Dis 1989; 9: 273-7.

16 Davis GL, Ballart LA, Schiff ER, Lindsay K, Bodenheimer HC, Perrillo RP, et al. Treatment of chronic hepatitis C with recombinant interferon alpha. A multicentre ran-
domized controlled trial. $N$ Engl $f$ Med 1989; 321: 1501-6.

17 Causse X, Godinot H, Ouzan D, Chevalier M, Chossegros $\mathrm{P}$, Zoulim F, et al. Comparison of 1 or $3 \mathrm{MU}$ of interferon alpha-2b and placebo in patients with chronic non- $A$, alpha-2b and placebo in patients with chronic non-A

18 Marcellin P, Boyer N, Giostra E, Degott C, Couroucé AM, Degos F, et al. Recombinant human $\alpha$-interferon in patients with chronic non-A, non-B hepatitis: a multicentre randomized controlled trial from France. Hepatology 1991; 13: 393-7.

19 Saracco G, Rosina F, Abate ML, Chiandussi L, Gallo V Cerutti E, et al. Long-term follow-up of patients with chronic hepatitis $\mathrm{C}$ treated with different doses of interferon $\alpha-2 b$. Hepatology 1993; 18: 1300-5.

20 Reichen J, Solioz M, Buhler H, Gonvers JJ, Knoblauch M Lavanchy $\mathrm{D}$, et al. Low-dose interferon in chronic non-A, non-B hepatitis: effects on quantitative liver function and structure in a randomized, controlled, multicentre trial. structure in a randomized, contrin
Clin Investig 1993; 71: 888-93.

21 Varagona G, Brown D, Kibbler H, Scheuer P, Ashrafzadeh $P$, Sherlock $S$, et al. Response, relapse and re-treatment rates and viremia in chronic hepatitis $C$ treated with $\alpha-2 b$
interferon alpha: A phase III study. European fournal of interferon alpha: A phase III study. European fou

22 Kagawa T, Morizane T, Saito H, Miyaguchi S, Tsunematsu $S$, Tada S, et al. A randomized, controlled trial of lymphoblastoid interferon in patients with chronic hepatitis C. F Hepatol 1993; 17: 91-6.

23 Simmonds P, Rose KA, Graham S, Chan SW, Lin CK, McOmish F, et al. Mapping of serotype-specific, immunodominant epitopes in the NS-4 region of hepatitis virus (HCV): use of type-specific peptides to serologically differentiate infections with HCV type 1,2 and 3 . 7 Clin Microbiol 1993; 31: 1493-503.

24 Simmonds P, Zhang LQ, Watson HG, Rebus L, Ferguson $\mathrm{ED}$, Balfe $\mathrm{P}$, et al. Hepatitis $\mathrm{C}$ quantification and sequenc-
ing in blood products, haemophiliacs, and drug users. ing in blood products, haem

25 Chomczynski P, Sacchi N. Single-step method of RNA isolation by acid guanidium thiocyanate-phenol-chloroform extraction. Ann Biochem 1987; 162: 156-9.

26 Garson JA, Ring C, Tuke P, Tedder RS. Enhanced detection by PCR of hepatitis C virus RNA [Letter]. Lancet 1990; 336: 878-9.

27 Hoofnagle $\mathrm{JH}$, Mullen $\mathrm{KD}$, Jones $\mathrm{DB}$, Rustgi $\mathrm{V}, \mathrm{Di}$ Bisceglie A, Peters $M$, et al. Treatment of chronic non-A, non-B hepatitis with recombinant human alpha-interferon. A preliminary report. $N$ Engl f Med 1986; 315: 1575-8.

28 Tiné F, Magrin S, Craxí A, Pagliaro L. Interferon for nonA, non-B chronic hepatitis: a meta-analysis of randomized clinical trials. F Hepatol 1991; 13: 192-9.

29 Iino S, Yasuda K, Sainokami S, Hino K. Treatment of chronic hepatitis $\mathrm{C}$ with interferon- $\alpha$. In: Nishioka $\mathrm{K}$ Suzuki $\mathrm{H}$, Mishiro $\mathrm{S}$, Oda $\mathrm{T}$, eds. Viral hepatitis and liver disease. Tokyo: Springer-Verlag, 1994: 607-9.

30 Davis GL. Prediction of response to interferon treatment in chronic hepatitis C. 7 Hepatol 1994; 21 : 1-3.

31 Jouët P, Roudot-Thoraval F, Dhumeaux D, Métreau JM, and Le Groupe Français pour l'Etude du Traitement des Hépatites Chroniques NANB-C. Comparative efficacy of interferon alfa in cirrhotic and non-cirrhotic patients with non-A, non-B, C hepatitis. Gastroenterology 1994; 106: non-A,

32 Pagliaro L, Craxí A, Cammaá C, Tiné F, Di Marco V, Lo Iacomo $\mathrm{O}$, et al. Interferon- $\alpha$ for chronic hepatitis $\mathrm{C}$ : an analysis of pretreatment clinical predictors of response. Hepatology 1994; 19: 820-8.

33 Pérez R, Pravia R, Linares A, González M, Rodríguez M,
Lombraña JLS, et al. Treatment of chronic hepatitis $\mathrm{C}$ with recombinant interferon alfa-2b for nine months. Gut 1992; 34 (suppl): S136-8.

34 Serfati L, Giral P, Loria A, Andreani T, Legendre C, Poupon R. Factors predictive of the response to interferon in patients with chronic hepatitis C. $\mathcal{F}$ Hepatol 1994; 21 12-7.

35 Weiland O, Schvarcz R, Wejstal R, Norkrans G, Fryden A. Therapy of chronic post-transfusion non-A, non-B hepatitis with interferon alfa-2b: Swedish experience. $f$ Hepatol 1990; 11 (suppl 1): S57-62.

36 Battezzati PM, Podda M, Bruno S, Zuin M, Crosignani A, Camisasca $M$, et al. Factors predicting early response to treatment with recombinant interferon alpha-2a in chronic non-A, non-B hepatitis. Preliminary report of long term trial. Ital $\mathcal{f}$ Gastroenterol 1992; 24: 481-4.

37 Yoshioka K, Kakumu S, Wakita T, Ishikawa T, Itoh I, Takayanagi $M$, et al. Detection of hepatitis $C$ virus by polymerase chain reaction and response to interferon alpha therapy: relationship to genotypes of hepatitis $C$ virus. Hepatology 1992; 16: 293-9.

38 Tsubota A, Chayama K, Ikeda K, Yasuji A, Koida I, Saitoh $\mathrm{S}$, et al. Factors predictive of response to interferon-a therapy in hepatitis C virus infection. Hepatology 1994; 19: 1088-94.

39 Mita E, Hayashi N, Hagiwara H, Ueda K, Kanazawa Y, Kasahara A, et al. Predicting interferon therapy efficacy from hepatitis $\mathrm{C}$ virus genotype and RNA titer. Dig Dis $S_{c i}$ 1994; 39: 977-82.

40 Chemello L, Pontiso P, Rose KA, Simmonds P, Bonetti P, Cavalletto $\mathrm{L}$, et al. The long-term response (LTR) to interferon-alfa (IFN-2A) in chronic hepatitis $C$ is influenced by dose and duration of treatment and the HCV serotype [Abstract]. $\mathcal{F}$ Hepatol 1993; 18 (suppl 1): S10

41 Bellobuono A, Mondazzi L, Tempini S, Bellati G, Cassar $\mathrm{L}$, Lombino $\mathrm{M}$, et al. Efficacy of different regimens of $\alpha$ interferon in chronic hepatitis $\mathrm{C}$ and relationship between response and HCV genotype [Abstract]. $\mathcal{F}$ Hepatol 1994; 21 (suppl 1): S35.

42 Reichard O, Foberg U, Fryden A, Mattsson L, Norkrans G, Sonnerborg A, et al. High sustained response rate and clearance of viremia after treatment with interferon-alpha clearance of viremia after treatment with inter 60 weeks. Hepatology 1994; 19: 280-5.

43 Bosch O, Tapia L, Quiroga JA, Carreno V. An escalating dose regime of recombinant interferon-alpha- $2 \mathrm{~A}$ in the treatment of chronic hepatitis C. F Hepatol 1993; 17: 146-9.

44 Camps J, Crisóstomo S, Garcia-Granero M, Riezu-Boj JI, Civeira MP, Prieto J. Prediction of the response of chronic hepatitis $C$ to interferon alfa: a statistical analysis of pretreatment variables. Gut 1993; 34: 1714-7.

45 Chemello L, Alberti A, Rose K, Simmonds P. Hepatitis C serotype and response to interferon therapy [Letter]. $N$ Engl F Med 1994; 330: 143

46 Dusheiko G, Alberti A, Colombo M, Craxi A, Frost C Prieto J, et al. The influence of serotypes of hepatitis C virus on sustained response to alpha interferon treatment [Abstract]. F Hepatol 1994; 21 (suppl 1): S17.

47 Ampurdanés $S$ Vilella $A$, Olmedo $E$ Maluenda $M D$ López-Labrador FX, Costa J, et al. Hepatitis C virus serotype and response to interferon in chronic hepatitis $C$ [Abstract]. f Hepatol 1994; 21 (suppl 1): S23.

48 Suzuki T, Tanaka E, Matsumoto A, Urushihara A, Sodeyama T. Usefulness of simple assays for serum concentration of hepatitis C virus RNA and HCV genotype in predicting the response of patients with chronic hepatitis to interferon- $\alpha 2 \mathrm{a}$ therapy. $\mathcal{F}$ Med Virol 1995; 46: 162-8.

49 Davis GL, Lau JY, Urdea MS, Neuwald PD, Wilber JC, Lindsay $\mathrm{K}$, et al. Quantitative detection of hepatitis $\mathrm{C}$ virus (HCV) RNA by a solid-phase signal amplification method: definition of optimal conditions for specimen collection and clinical application in interferon treated patients. Hepatology 1994; 19: 1337-41.

50 olmedo E, Forns X, Ampurdanés S, Maluenda MD López-labrador FX, Costa J, et al. Evaluación de la replicación del virus de la hepatitis $\mathrm{C}$ (VHC), su relación con el genotipo viral, la gravedad de la enfermedad y la respuesta al tratamiento [Abstract]. Gastroenterol Hepatol 1995; 18: 266 